\title{
Genesis of the Russian agro-industrial complex: historical and legal aspect
}

\author{
Olga Kichalyuk $^{1 *}$ and Oksana Morozova ${ }^{1}$ \\ ${ }^{1}$ Institute of Service and Entrepreneurship (branch) of DSTU in Shakhty, 147, Shevchenko str. \\ 346500, Shakhty, Russia.
}

\begin{abstract}
The article examines the genesis of the agro-industrial complex of Russia in the historical and legal aspect. The authors analyze the stages of the development process of the agrarian sector of the Russian economy, covering the period from 1918 to 2000, noting both positive and negative events that took place locally in the state policy of the country for the specified period. The authors emphasize that at the turn of the $1980 \mathrm{~s}$ and 1990 s, the socialist system of regulation of the economic mechanism of the agro-industrial complex completely outlived its usefulness, which contributed to the adoption of political decisions that marked the beginning of the modern stage of development. agrarian reform in Russia. Today, in a difficult foreign policy situation, the preconditions are being created within the country to stimulate and develop the domestic agro-industrial complex, which is the basis of the country's food security.
\end{abstract}

\section{Introduction}

The agro-industrial complex is one of the largest intersectoral economic complexes. It includes diverse areas of the economy, including agriculture and certain industries associated with agricultural production.

Traditionally, the agricultural sector occupies a special position in the Russian economy. Semin A.N. and Kibirov A.Ya., this sector is "one of the key and priority components in the system of the national economic complex, since it ensures the food and national security of the country" [1]. The problems of its functioning affect the interests of the entire state. And they arise quite often, which is associated with the static nature of the agricultural sector, which has difficulty adapting to changing market conditions.

Possessing significant natural resources, possessing significant human, scientific and educational potential, Russia could take a leading position in the world market for the production of essential food products. Meanwhile, the unstable development of the domestic agro-industrial complex, given a long-term period of stagnation and degradation of all sectors of the economy, has led to numerous problems in this area. The current state of the agro-industrial complex depends on many factors - state strategy, level of funding, technical production capabilities, historical conditions of development.

*Corresponding author : olga.kichalyuk@mail.ru 
The long-term agrarian orientation of Russia after the abolition of serfdom in 1861 allowed agriculture to make a breakthrough in several key positions in the world market. In particular, by the beginning of the 20th century, domestic grain producers came out with leading indicators as leading exporters in the world market. More than half of the national income came from agricultural products.

The backward technical equipment of the agrarian complex, the traditional system of land cultivation, the lack of an effective system of land management did not allow the peasantry to increase the yield and quality of products, therefore, in 1907, the first attempts were made to reconstruct agriculture within the framework of the Stolypin reform.

As a result, it was possible to create a class of rural entrepreneurs, lay the foundations of the banking system and rural cooperation, increase production volumes and expand the possibilities of the domestic market. With the advent of Soviet power, the situation did not stabilize, since the positive fruits of the New Economic Policy, which improved agriculture, were replaced by collectivization, which had known negative results.

However, as A. Rakov notes, "in addition to the subjective management factors that provoked the crisis in the countryside, it is necessary to note objective problems, including the refusal of the transition of Russian agriculture to intensive multi-floor crop rotations, which in the West occurred much earlier and formed an effective way of management" [2].

\section{State legal regulation of the agricultural sector in the Soviet period}

The development of agro-industrial complexes in Russia began at the end of the 1920s with the formation of agro-industrial complexes producing, processing and selling agricultural products. However, weak legal regulation, unfavorable economic situation did not contribute to the further development of integration, which received a new impetus only in the early 70 s.

The agro-industrial complex includes regional complexes and small formations: associations, agricultural holdings, agricultural firms.

The agro-industrial complex is a complex of industries with close economic and production relationships. One of the main conditions for the dynamic development of the agro-industrial complex is the proportionality and balance of all its components.

For more than a century of Russian history, the regulation of the agrarian economy was carried out by both administrative and economic measures. In the historical aspect, these methods replaced each other in turn.

The administrative method of regulation can be considered the policy of "war communism" during the civil war and military intervention in 1918-1920. The earliest example of an attempt at legal regulation is the proclamation of the New Economic Policy in 1921. The new economic policy was characterized by sharp contradictions, lack of integrity of approaches to management between economic and administrative methods. Handicraft and small-scale production developed in the form of both private and cooperative enterprises. By 1930, economic policy had collapsed as administrative measures were tightened. The new economic policy improved agriculture, but the most acute political struggle led to its curtailment.

The next historical stage is the process of "collectivization", that is, the unification of the peasantry into collective farms under state control. In the process of collectivization, two types of farms were formed: collective farms and state farms. The formation of the agro-industrial complex began in 1930 during the period of industrialization and technical 
reconstruction of the national economy. The country created branches of tractor and agricultural engineering, for the production of mineral fertilizers, and the light and food industries developed. Fundamental changes have taken place in the socio-economic structure of agriculture: collective and state farms have become the main links in agricultural production, their ties with industry and other sectors of the national economy have significantly strengthened.

The emergence of the term "agro-industrial complex" refers to the 1960-1970s. The formation of the agro-industrial complex as an economic phenomenon contributed to the creation of a specialized system of public administration. In the Soviet period, the concept of "public administration" in relation to the agro-industrial complex was viewed as an exclusively unilateral power process of state influence on certain areas of public life. The main stages in the development of the agricultural sector of Soviet Russia in 1920-1970 are presented in Table 1.

Table 1. Stages of development of the agrarian sector of Soviet Russia in 1920-1970.

\begin{tabular}{|c|l|}
\hline Period & \multicolumn{1}{|c|}{ State measures } \\
\hline $1918-1920$ years & The policy of "war communism" \\
\hline $1921-1930$ years & "New Economic Policy" (NEP) \\
\hline $1930-1939$ years & $\begin{array}{l}\text { "Collectivization" - the unification of the peasantry into collective } \\
\text { farms (collective and state farms) under state control }\end{array}$ \\
\hline $1940-1970$ years & $\begin{array}{l}\text { Formation of the agro-industrial complex as an economic } \\
\text { phenomenon }\end{array}$ \\
\hline
\end{tabular}

In the 1980s, an attempt was made to create a unified specialized system of state administration bodies for agriculture and agro-industrial integration, including several levels: the Union-Republican Gosagroprom of the USSR - agricultural industries of the union republics - agricultural industries in the autonomous republics, territories and regions - district and regional agro-industrial associations. However, this centralized management system, based primarily on administrative command methods of managing agriculture, turned out to be ineffective.

Assessing the overall management system of the agro-industrial complex, which developed in the USSR and the RSFSR in the 1980s, I would like to say that neither the norms of the USSR Law "On a State Enterprise (Association)", nor the Resolution of the Central Committee of the CPSU and the USSR Council of Ministers of December 18, 1987 "On the reorganization of the unprofitable enterprise up to the termination of its activities" did not work in reality. The nationalization of the economy gave rise to the lack of economic responsibility of enterprises. The economic results for them did not really matter, since the state took a significant part of the profits from profitable enterprises, and the necessary financing represented the unprofitable ones. Under such conditions, the bankruptcy of an individual enterprise was impossible.

The collective responsibility of enterprises and associations was closely linked in Soviet law with individual (personal) responsibility, as well as the responsibility of teams and divisions for the final results of the work of the entire team. Persons, through whose fault it was admitted failure to fulfill obligations under contracts, could either be partially or completely deprived of bonuses based on the results of work for the year, or were obliged to reimburse costs at the expense of funds provided for wages and bonuses. 
During the period under review, finding itself in a financial crisis, the Soviet Government tried to modernize the agro-industrial complex. Moreover, it subsequently made timid attempts to raise food prices. The political complexity of such unpopular decisions is quite understandable, since it is difficult to explain to the population a tenfold increase in food prices without visible signs of a crisis in national life. The efforts made were clearly not enough to remove the accumulated problems.

Due to the current difficult economic situation and the lack of government support, many agricultural enterprises were ruined. Thus, the reform of the agri-food sector by the early 1990s became urgently needed. Hence, its main tasks followed: a radical change in the agrarian system, the introduction of more efficient production relations in the sector, and a decrease in its pressure on the budget. In terms of the scale, the replacement of state agriculture by market-oriented one was incomparable with the insignificant steps of improving the economic mechanism of the Soviet period. It required a revision of almost all systems - pricing, financial and credit mechanism, supply and sales of products. Moreover, there was a difficult adaptation of enterprises and population to fundamentally new market conditions. All this unambiguously led to a decline in production and the rupture of established ties. Accordingly, at the turn of the 1980s-1990s, the socialist system of regulation of the economic mechanism of the agro-industrial complex completely outlived its usefulness.

\section{State and legal aspects of the agrarian reform of $1991-2000$}

At the end of 1991, the main decisions were made, which marked the beginning of the modern stage of the agrarian reform. In 1992, the reorganization of collective and state farms began, which assumed: first, the transfer of land and non- land means of production to the ownership of labor collectives of agricultural enterprises, the second, the division of these funds into individual shares, and the third, re-registration of farms in one of the organizational and legal forms permitted by the relevant legislation of that period.

Land reform and restructuring of agricultural producers in Russia were based on the division of land into shares. Collective and state farm workers, their pensioners and social workers received equal conditional shares in the land use of their farms. These shares were not marked on the ground, and they could be considered as a kind of options: they gave the owner the right to receive a plot in kind at any time and without the consent of other owners of shares, only the location of the plot was a subject of discussion. These shares have been the subject of all kinds of transactions.

During 1992-1994, about 12 million shares were distributed to rural residents . About 300 thousand households exercised their right to leave collective farms and organize their own family farms. The rest of the villagers preferred to retain the status of hired workers; as a rule, they rented out their land shares to their farms.

Due to the low legal culture and the level of enforcement of land shares were poorly decorated legally, their owners do not imagine the benefits and of the duties of ownership stakes and agricultural actually use the land without paying rent. Moreover, the land leased in the form of land shares was not limited locally. In a federal state regulation of land issues were relegated to the sphere of joint conduct of federal and regional authorities, and to some areas of the federal legislation on the Earth is divided into land shares not been put into legal force.

The situation changed somewhat after the adoption, which had already lost its legal force, the Decree of the President of the Russian Federation "On the implementation of the 
constitutional rights of citizens to land" dated March 7 , 1996, No. 337, which obliged all land users to enter into formal contracts with owners of land shares [3] . From that point on, the average size of family farms began to grow by renting shares. There was no official data on land transactions between agricultural enterprises, but such a practice did exist. The decree motivated the owners of the shares to look for more favorable terms of rental deals. As a result, a para-market for land shares was formed in the country .

The devaluation of the ruble in 1998 contributed to significant import substitution and a fairly significant growth in agriculture over the following years. As a result, the demand for land has increased, it has acquired value. And the conventionality of land shares played a positive role in the development of the land market. On the one hand, non-agricultural investors attracted by the high profitability of the agricultural sector and interested in vertical integration due to high transaction costs began to acquire farmland for their own production. On the other hand, the owners of shares began to be wary of selling them, realizing the value of their land rights. Thus, access to land at that time could be obtained primarily through the lease of shares.

When would the reform land was divided physically, large companies, who rented the large tracts of land, had to detract from productive investment funds for land consolidation. And so they accumulated in their hands a large number of leased land shares and only after that made demands on the farms for the allocation of land in kind, which allowed them to receive large plots in single tracts.

On the other hand, the owner of the share, while remaining its owner, after the expiration of the lease agreement, could demand the allocation of a plot on the border of the lessee's land use. With the physical allotment of shares after the expiration of the lease term, the plot could be in the middle of the tenant's crop rotation. Such a threat would discourage the owner of the site from renting it out.

After 1998, the market for land shares developed quite rapidly. According to various estimates, about $5-6 \%$ of farmland changes its users every year. Such an active market demanded high-quality land legislation, so the new Land Code of the Russian Federation [4] and the Law "On the Turnover of Agricultural Lands" [5] easily passed through the lower house of parliament at the end of 2001 - after years of stormy but futile public discussions.

As a result of the reforms, a rather contradictory agrarian structure has developed in Russia. Agricultural enterprises have used bases hydrochloric piece of farmland and arable land, while IU made her half of the gross output. It seemed that they continued to use their former areas, and production was concentrated in family farms. But private farms any noticeably increased their production, with the exception of potatoes, vegetables and fruit. During the period under review, personal subsidiary plots produced products mainly for their own consumption. Thus, the sharp decline in agricultural production reflected an equally sharp decline in food consumption in the country since the beginning of reforms. Due to the reduction in the purchasing power of the population fell to demand food and production to market-oriented farms in that same proportion as that while individual farms focused on auto-consumption, etc. rodolzhili previous production. In addition, as noted by Gnezdova , JV, Semchenkova , SV, Kuchumov , AV “ From 1995 to 2000. n roizoshlo reducing the number art. Almost complete liquidation of large agricultural enterprises, transfer of equipment to agriculture. personal subsidiary plots, the crisis situation of other enterprises led to the loss of the machine and tractor fleet" [6].

Growth in the agricultural sector has accelerated the differentiation of agricultural producers in Russia. Some of them used the opportunity and about tkryvsheesya with the devaluation of the ruble in yrosli their income, they have to repay the accumulated debt, 
reinvest profits, to attract foreign investment to the sector. At the other extreme, agricultural enterprises and in the past, agricultural territories became unprofitable, producers accumulated bad debts, there was a rapid decapitalization, and land was abandoned. The prime cost of the main types of products, even in relatively similar conditions of the same territory, differed at the enterprises dozens of times.

Changes in principles and approaches of state regulation of social relations in the context of liberal reforms in 1991-1999 years have led to the expansion of the scope of discretionary regulation. The situation in the domestic agro-industrial complex during this period was of a crisis nature, which is explained by the lack of real, clear and clear ideas about the directions and ways of development of the industry, a low degree of control at the federal, regional and local levels, weak legal regulation of the industry, as well as a lack of funds to create efficient infrastructure and competitive production.

\section{Problems of the functioning of the agro-industrial complex of Russia in the 2000s}

In the early 2000s, many registered agricultural producers in Russia did not actually carry out economic activities. As a result, a high share of low-profit producers remained on the market, which reduced the efficiency of the sector as a whole.

Moreover, the withdrawal of inefficient producers from the market would free up a market niche for efficient ones, which could increase production and further increase their efficiency. This situation has developed primarily due to the lack of a legal mechanism for bankruptcy of enterprises and an optimal policy for the development of the agricultural sector aimed at creating alternative rural employment. As Bukhtiyarova, T.I., Semin, A.N., Demyanov, D.G., Tenetko, A.A., Nemykina, Yu.S. "New models of organization of agricultural production and management are the basis for the stability of trends in rural development in the long term" [7].

Small individual producers, represented by personal subsidiary plots, are also strongly polarized, since half of the farms remain purely subsidiary and produce products only for personal consumption, and income from occasional sales does not have a noticeable effect on the family budget. Market-oriented commercial producers are not registered as farms in order to avoid taxation and maintain access to the services of the basic farm. After the financial crisis, external investors came to the agricultural sector, who created large agroindustrial holdings on vast land tracts. Both the investors themselves and their motives varied. Processors and traders, due to the rise in the cost of imported raw materials, began to work with domestic suppliers and faced huge transaction costs. This prompted them to vertically integrate the food chain, primarily agricultural production. Other investors came from the oil, gas, financial sectors, seeking to diversify their businesses in order to reduce financial risks.

In both cases, it was the fact that agriculture showed high returns with insignificant initial investments in the context of more or less competent management and preferential taxation regime. Today the holdings play a leading role in the modernization of agriculture. A striking example of a holding that carries out such activities is the Rostselmash Group, which includes 13 enterprises with production sites in four countries. Since its inception, Rostselmash has delivered more than 2.6 million combines to its customers in different countries.

\section{Conclusion}


The unsuccessful agricultural policy pursued in the 90s left its mark on the industry as a whole, but in the 2000s the situation returned to normal due to the provision of state support to farmers and the establishment of a system of agricultural insurance and lending, the development indicators of the industry began to grow.

Regions with a low share of the agricultural sector in the economy, located in zones with the least favorable natural and climatic conditions for agricultural production, have high budgetary opportunities for financing the agricultural sector. Shifting the center of gravity in budgetary support to the agro-industrial complex from the federal to the regional level means stimulating agricultural production in these regions. In addition, "trade wars" between the constituent entities of the Russian Federation are escalating, neighbors are being squeezed out of the all-Russian market by direct subsidizing of their own producers, and bans are being introduced on the movement of agri-food products across the country.

To avoid such negative consequences, the Ministry of Agriculture retained partial subsidies for agriculture, transferring some subsidies to inter-budgetary transfers of the agro-industrial complex. Since 2006, subsidies for livestock breeding and elite seed production, interest rates on loans, insurance support and even the delivery of seeds to the northern regions are financed only in the form of inter-budget transfers. Such subsidies, firstly, make the agrarian budget opaque: less than half of subsidies to agriculture are financed under the subsection "Agriculture" of the functional classification of expenditures, the rest is reflected under the section "Interbudgetary transfers". Secondly, it strongly distorts the regional agrarian policy. Since federal transfers are provided on the terms of cofinancing, all regions are beginning to apply these programs on their territory so as not to lose federal transfers and receive as much federal money as possible. The effectiveness of the corresponding federal programs and the spending of regional budget funds for cofinancing is extremely low.

In addition, this deprives the regions of funds for the implementation of their own programs, which are often more effective than federal programs and are more in line with the development priorities of the region's agro-industrial complex. In addition, this deprives the regions of funds for the implementation of their own programs, which are often more effective than federal programs and are more in line with the development priorities of the region's agro-industrial complex.

As noted, Bazenov A.B., Begzhan A.M., Zhunisov Z.S., Tazhikov A.K., Amandosuly "the transitional stage in the agrarian economy requires an optimal combination of state protection and market levers. At present, the regulatory influence of the state on the development of the agrarian economy remains, on the one hand, quite significant, and on the other, insufficiently effective" [8].

As noted by Mamychev, A.Yu., Ivanova, O.V., Ranchinskaya, Y.S., Kobersy, I.S., "recently, government agencies have begun to consider the agricultural sector of the economy and its development as priorities of state policy" [9]. In particular, a number of federal and regional programs have been adopted to address the country's accumulated economic and social problems.Assessment of the state's actions in the last decade indicates an increase in its role in solving issues of supporting the agro-industrial complex with the help of federal target programs, decrees and orders of the President of the Russian Federation. As noted by O. Kichalyuk and O. Morozova, "the head of state has a special place in the system of state authorities. However, this situation does not allow us to interpret the power of the President of Russia as towering over all other branches of government" [10]. This leads to the conclusion that the main support of the agro-industrial complex should be based on federal laws passed by parliaments, not decrees and orders of the head of state. However, all these measures are focused primarily on import substitution. 
As E. Krasnoperova notes, the Russian economy is going through difficult times [11]. Corruption and opacity lead to unreasonable increases in the prices of agricultural products. We agree that the best way to support agricultural production in the state is to increase investment costs for roads or education in rural areas [12]. According to the fair judgment of Cherkesova, E., Mironova, D., Demidova, N. "economic and food security are becoming a priority for the state in conditions of high political instability and disruption of foreign economic relations" [13]. We are in solidarity with the opinion of Fastovich, G.G., Kapsargina, S.A., according to which "the modernization of the agro-industrial complex will allow the Russian Federation to improve its national agricultural policy, as well as to strengthen the spheres of influence in the international arena" [14].

For Russia, as for all countries of the world, according to Yarlykapov A., Bembetov A., food security is the most important direction of state policy and a factor of sustainable development [15]. According to the position of VP Neganova and A. Dudnik, "to implement active import substitution in key industries, enter foreign markets and more actively build structures of economic integration, alternative to the existing ones, it is necessary to solve many derivative problems in each sector of the Russian economy" [16].

Thus, in the context of a difficult foreign policy situation, the preconditions are being created within the country to stimulate and develop the domestic agro-industrial complex, which is the basis of the country's food security.

\section{References}

1. A. Semin, A. Kibirov, U. Rassukhanov, European Research Studies Journal, 21(2), 378-400 (2018) doi: 10.35808/ersj/1009

2. A. Rakov, Zhournal Novoi Ekonomicheskoi Associacii, 48(4), 162-183 (2021) doi: 10.31737/2221-2264-2020-48-4-7

3. Decree of the President of the Russian Federation of 07.03.1996 No. 337 (as amended on 25.01.1999) "On the implementation of the constitutional rights of citizens to land"

4. Land Code of the Russian Federation of 10/25/2021 No. 136-FZ (as revised on 12/30/2020)

5. Federal Law of July 24, 2002 No. 101-FZ (as amended on June 6, 2019) "On the turnover of agricultural land"

6. J. Gnezdova, S. Semchenkova, A. Kuchumov, IOP Conference Series: Earth and Environmental Science, 459(6), 062061 (2020) doi: 10.1088/1755-1315/459/6/062061

7. T. Bukhtiyarova, A. Semin, D. Demyanov, A. Tenetko, Y. Nemykina, IOP Conference Series: Earth and Environmental Science, 548(2) 22055 (2020) doi: $10.1088 / 1755-1315 / 548 / 2 / 022055$

8. A. B. Bazenov, A. M. Begzhan, Z. S. Zhunissov, A.K. Tazhikov, B. Amandossuly, International Journal of Criminology and Sociology, 9, 3175-3186 (2020) doi: 10.6000/1929-4409.2020.09.384

9. A. Mamychev, O. Ivanova, Y. Ranchinskaya, I. Kobersy, International Journal of Applied Business and Economic Research, 15(12), 35-42 (2017)

10. O. Kichalyuk, O. Morozova, Man in India, 97(23), 363-373 (2017)

11. E. Krasnoperova, E3S Web of Conferences, 176, 05003 (2020) doi: $10.1051 /$ e3sconf/202017605003

12. S. Zakharin, S. Stoyanova-Koval, I. Kychko, V. Marhasova, I. Shupta, Journal of Optimization in Industrial Engineering, 14(1), 209-218 (2021) 
13. E. Cherkesova, D. Mironova, N. Demidova, E3S Web of Conferences, 175, 13020 (2020) doi: 10.1051/e3sconf/202017513020

14. G. Fastovich, S. Kapsargina, IOP Conference Series: Earth and Environmental Science, 421, 032035 (2020) doi:10.1088/1755-1315/421/3/032035

15. A. Yarlykapov, A. Bembetov, Oriental Studies, 8(2), 185-188 (2015)

16. V. Neganova, A. Dudnik, Economy of Region, 14(2), 651-662 (2018) doi:10.17059/2018-2-25 